\title{
Steroid-responsive nephrotic syndrome and allergy: immunological studies
}

\author{
S R MEADOW, J K SARSFIELD, D G SCOTT, AND S M RAJAH \\ Department of Paediatrics and Child Health and Department of Immunology, University of Leeds; \\ Regional Blood Transfusion Centre, Leeds; St James's University Hospital, Leeds
}

SUMMARY Immunological studies were performed on 84 children with steroid-sensitive nephrotic syndrome as part of an investigation of the relationship between steroid-responsive nephrotic syndrome and allergy. Serum total IgE levels tended to be raised, particularly in children who had frequent relapses of nephrotic syndrome. Ten children had extremely high levels $(>1500 \mathrm{IU} / \mathrm{ml})$ and several of them had neither a history of atopy nor any other identifiable cause. $25 \%$ of the children had at least one positive test for specific IgE antibody. IgE was not detected by immunofluorescence in renal biopsy tissue from 25 children, regardless of whether the child was in remission or relapse at the time of biopsy. Serum IgG and IgA levels were depressed particularly at the time of a relapse. Serum IgM tended to be raised and to remain so, even in children who had been in remission for more that a year. No clinically useful relationship was found between the frequency of HLA antigens and the occurrence or course of the syndrome, whether or not accompanied by atopy. Clinical and immunological features of atopy are more common in children with idiopathic nephrotic syndrome. This may be a causal or non-causal association. Pollen sensitivity is a rare cause of nephrotic syndrome; careful search for provocative agents may show other causes.

Clinical features of allergy are more common in children with steroid-sensitive nephrotic syndrome than in normal children. ${ }^{1}$ Rarely nephrotic syndrome occurs as a result of pollen hypersensitivity.

In an atopic person the antigen-provoked disorder is associated with the production of high levels of immunoglobulin $\mathrm{E}$ (IgE) antibody to at least one common antigen. There have been contradictory reports of excess $\operatorname{IgE}$ in the serum and renal tissue of children with nephrotic syndrome.

This paper reports the immunological findings in a group of children with steroid-responsive nephrotic syndrome who had undergone detailed clinical studies for allergy. Circulating $\operatorname{IgE}$ and specific $\operatorname{IgE}$ in particular were considered in relation to other immunoglobulin levels, clinical state, and the immunofluorescent findings in renal tissue.

In addition, because of previous reports of a probable linkage between HLA antibody status and nephrotic syndrome, the HLA status of this carefully studied group was assessed.

\section{Methods}

Children. Details of the children are given in the previous paper (page 509). ${ }^{1}$

\section{Nephrotic syndrome}

This group comprised 62 boys and 22 girls with steroid-sensitive nephrotic syndrome who had been shown to have, or were believed to have, minimal change histology. Twelve of them had each had only a single bout of nephrotic syndrome (single nephrotic syndrome). Seventy-two had had relapses, most of them frequent ones (relapsing nephrotic syndrome). At the time of investigation all had been in remission for longer than one month.

\section{Control group $A$}

This group comprised 80 control children from a general paediatric outpatient clinic.

Investigations. Serum immunoglobulin IgA, IgG, and IgM were measured by a single radial immunodiffusion technique ${ }^{2} 3$ using plates from Boehringer laboratories.

The immunoglobulin levels of the nephrotic children were measured in international units $/ \mathrm{ml}$ and were then converted to a percentage mean value for age (or, in the case of IgM, a percentage mean value for age and sex). The conversion tables prepared by Hoechst pharmaceuticals were used; these use the mean of 6 different surveys as a reference source. ${ }^{4-9}$ 
The mean value and the statistical variation are taken as: $0.6 \times$ to $1.6 \times$ for IgG, $0.4 \times$ to $2.4 \times$ for $\operatorname{IgA}$, and $0.5 \mathrm{x}$ to $2.0 \mathrm{x}$ for IgM.

Serum total IgE was measured by radioimmunoassay. ${ }^{10}$ The research standard $\operatorname{IgE}(68 / 341)$ was used as advised by Rowe et al. ${ }^{11}$ and expressed as units of IgE per $\mathrm{ml}$. The method had a coefficient of variation of $10 \%$.

Specific IgE in serum was detected by the radioallergosorbent test (RAST). ${ }^{12}$ On the early specimens, cord serum was used as a standard and a positive result was one that had more than double the cord serum background. This method proved comparable to the Pharmacia RAST kit for IgE; but for confirmation most specimens in the study were tested with the Pharmacia kit as well.

Renal tissue was obtained by percutaneous biopsy using a standard technique. ${ }^{13}$ The material for immunofluorescence was frozen on to chucks in a bench-mounted $\mathrm{CO}_{2}$ freezing unit, and cut at a thickness of $4 \mu \mathrm{m}$ in a cryostat at $-15^{\circ} \mathrm{C}$ before being mounted. An indirect immunofluorescent technique for detecting IgE was used. All sections were examined also for IgA, IgM, IgG, C1q, C3 complement components, and fibrin. Later in the study additional tests for $\mathrm{C} 4, \mathrm{C} 5$, and properdin were included.

Blood from the children with nephrotic syndrome was tested for 20 HLA antigens using a modification of the microlymphocytotoxic technique of Terasaki and $\mathrm{McClelland},{ }^{14}$ using lymphocytes separated from heparinised blood by density gradient centrifugation. ${ }^{15}$ The 60 antisera were obtained mainly from multiparous women and had been standardised to the National Institute of Health standards. Information about HLA types in the local population had been obtained previously, using blood from 458 healthy white adults who had volunteered as blood donors in Yorkshire. The frequencies of individual HLA types were analysed by $\chi^{2}$ with Yates's correction. Because 20 antigens were being compared, statistical correction of $P$ values was made using the technique of Grumet et al. ${ }^{16}$

\section{Results}

Serum total IgE. The range of IgE levels in 75 children is shown in Fig. 1. The distribution was skewed to the low levels and yet included a few extremely high levels. Most children had levels $<500 \mathrm{IU} / \mathrm{ml}$. Ten children had extremely high levels, up to a maximum of $10000 \mathrm{IU} / \mathrm{ml}$.

Of 48 children in the control group only one had a level $>1000 \mathrm{IU} / \mathrm{ml}$. It is clear that the number of children with very high levels would cause the mean

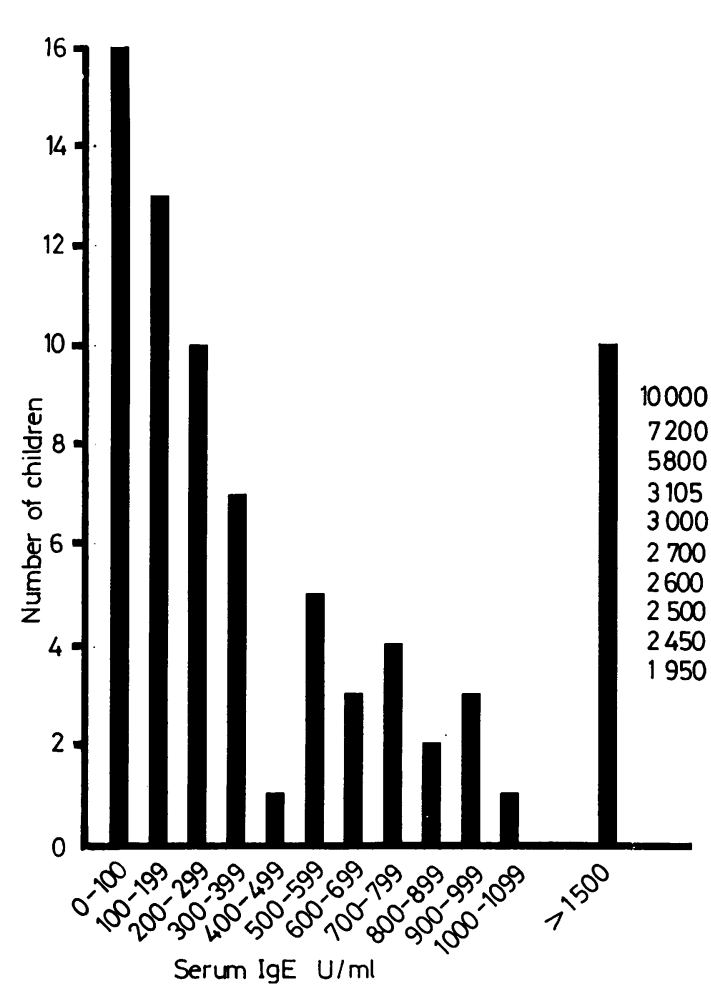

Fig. 1 Distribution of total serum IgE levels in 75 children with steroid-responsive nephrotic syndrome. Figures on right are the actual levels in 10 children in whom levels were particularly high.

serum IgE of the nephrotic children to be far greater than that of the controls. However, excluding all children with levels greater than $1000 \mathrm{IU} / \mathrm{ml}$, the arithmetic mean serum IgE of the nephrotic children is still greater than that of the controls.

The serum IgE levels tended to be lower in children with single attacks of nephrotic syndrome than in those with recurrent ones. Of the 10 with very high levels only 1 child had single nephrotic syndrome (Table 1).

Table 1 Serum total IgE levels in nephrotic and control children

\begin{tabular}{|c|c|c|c|}
\hline \multirow[t]{2}{*}{ Group } & \multicolumn{2}{|c|}{$I g E(I U / m l)$} & \multirow[t]{2}{*}{ Mean level } \\
\hline & $>1000$ & $0-1000$ & \\
\hline $\begin{array}{l}\text { Children with nephrotic syndrome } \\
\text { Controls }\end{array}$ & $\begin{array}{r}10 \\
1\end{array}$ & $\begin{array}{l}65 \\
47\end{array}$ & $\begin{array}{r}351 \\
79\end{array}$ \\
\hline $\begin{array}{l}\text { Nephrotic children with single } \\
\text { episode } \\
\text { Nephrotic children with frequent } \\
\text { relapses }\end{array}$ & 1 & 10 & 203 \\
\hline
\end{tabular}

Levels $>1000$ were excluded when calculating the mean. 
Twenty-seven children had at least 2 estimations of serum IgE while in remission and without having received treatment with cytotoxic drugs between estimations: most children retained a serum $\operatorname{IgE}$ level in the same range. The values (Table 2) show the results for 5 children who had at least 3 estimations.

Relationship to cyclophosphamide. Nine children had serum IgE measured in remission before and after an 8-week course of cyclophosphamide. Generally the levels after cyclophosphamide were lower than before and, in particular, 5 children in whom the initial level had been $>500 \mathrm{IU} / \mathrm{ml}$ had a level $<500 \mathrm{IU} / \mathrm{ml}$ after treatment with cyclophosphamide. The fall took place in children who benefited from cyclophosphamide and also in 2 children who derived little benefit (Table 3).

Relationship to atopy. High serum IgE levels tended to be associated with a history of at least one atopic disorder (Table 4). However, it is worth noting that

Table 2 Results of estimations of IgE in 5 children

\begin{tabular}{llrll}
\hline Case & \multicolumn{5}{l}{ Estimation $(I U / m l)$} \\
\cline { 2 - 5 } & \multicolumn{1}{l}{ Ist } & 2 nd & 3rd & 4 th \\
\hline 56 & 3000 & 2600 & 2300 & 4800 \\
19 & 38 & 92 & 32 & - \\
30 & 520 & 240 & 420 & - \\
43 & 320 & 100 & 125 & - \\
23 & 980 & 680 & 435 & 570 \\
\hline
\end{tabular}

Table 3 Serum total IgE levels before and after treatment with cyclophosphamide.

\begin{tabular}{|c|c|c|c|}
\hline \multirow[t]{2}{*}{ Case } & \multicolumn{2}{|c|}{$I g E(I U / m l)$} & \multirow{2}{*}{$\begin{array}{l}\text { Did treatment } \\
\text { lead to remission } \\
\text { of at least one } \\
\text { year }\end{array}$} \\
\hline & $\begin{array}{l}\text { Before } \\
\text { treatment }\end{array}$ & $\begin{array}{l}\text { After } \\
\text { treatment }\end{array}$ & \\
\hline $\begin{array}{r}17 \\
51 \\
56 \\
34 \\
45 \\
18 \\
29 \\
74 \\
1\end{array}$ & $\begin{array}{r}5000 \\
10000 \\
4400 \\
720 \\
920 \\
560 \\
230 \\
180 \\
145\end{array}$ & $\begin{array}{r}240 \\
80 \\
45 \\
270 \\
300 \\
380 \\
400 \\
60 \\
60\end{array}$ & $\begin{array}{l}\text { Yes } \\
\text { Yes } \\
\text { No } \\
\text { No } \\
\text { Yes } \\
\text { Yes } \\
\text { Yes } \\
\text { Yes } \\
\text { Yes }\end{array}$ \\
\hline
\end{tabular}

Table 4 Relationship of serum total IgE with a history of asthma, eczema, urticaria, or hay fever

\begin{tabular}{lll}
\hline Serum total IgE $(I U / m l)$ & History & \\
\cline { 2 - 3 } & Atopic & Non-atopic \\
\hline$<500$ & 9 & 38 \\
$500-1000$ & 8 & 10 \\
$>1000$ & 6 & 3 \\
\hline
\end{tabular}

Table 5 Prevalence of positive response to RAST

\begin{tabular}{lllr}
\hline \multicolumn{4}{c}{ Nephrotic syndrome } \\
\cline { 2 - 4 } & Number tested & Positive & $\%$ \\
\hline House-dust mite & 71 & 11 & 15 \\
Grass pollen & 71 & 6 & 8 \\
Cat fur & 68 & 8 & 12 \\
Dog hair & 71 & 3 & 4 \\
Milk & 71 & 7 & 10 \\
Egg & 74 & 5 & 7 \\
& 426 & 40 & 9.4 \\
\hline
\end{tabular}

$35 \%$ of the children had one or more positive test to the 6 allergens

Table 6 Results of tests on selected nephrotic children who might have been sensitive to an item or might have exceptional exposure to it

\begin{tabular}{ll}
\hline Rabbit & 1 positive out of 12 tests \\
Cereals & 0 out of 12 \\
Tomato & 0 out of 8 \\
Banana & 1 out of 5 \\
Fish & 0 out of 5 \\
Budgerigar & 0 out of 4 \\
Chocolate & 1 out of 4 \\
Other items & 0 out of 30 \\
\hline
\end{tabular}

3 children with levels $>1000 \mathrm{IU} / \mathrm{ml}$, and 10 with levels in the range $500-1000 \mathrm{IU} / \mathrm{ml}$ had no history of atopy.

Specific IgE. Seventy-four nephrotic children were tested for the presence of specific IgE antibodies to house-dust mite, grass pollen, dog hair, cat fur, milk, and eggs. $9.4 \%$ of these tests were positive (Table 5), but $26(35 \%)$ of these 74 children had at least one positive response to the RAST for the 6 allergens tested.

A further 80 tests were done to try to identify specific antibody to 16 other items. These further tests were done on selected nephrotic children, the indication for the test being any suggestion from the history that the child might be sensitive to that item, or might be subject to unusually heavy exposure to that item. The results of these tests are shown (Table 6).

\section{Serum IgG, IgA, and IgM.}

\section{IgG}

Of 60 children, 48 had values within the normal range, the other 12 had values significantly below the normal range. Fifty-three had a percentage mean value below $100 \%$. The mean level of the nephrotic children was $76 \%$ (Fig. 2).

\section{$\operatorname{Ig} A$}

Of 59 nephrotic children, 50 had a value within the normal range, 9 had a value significantly below the 


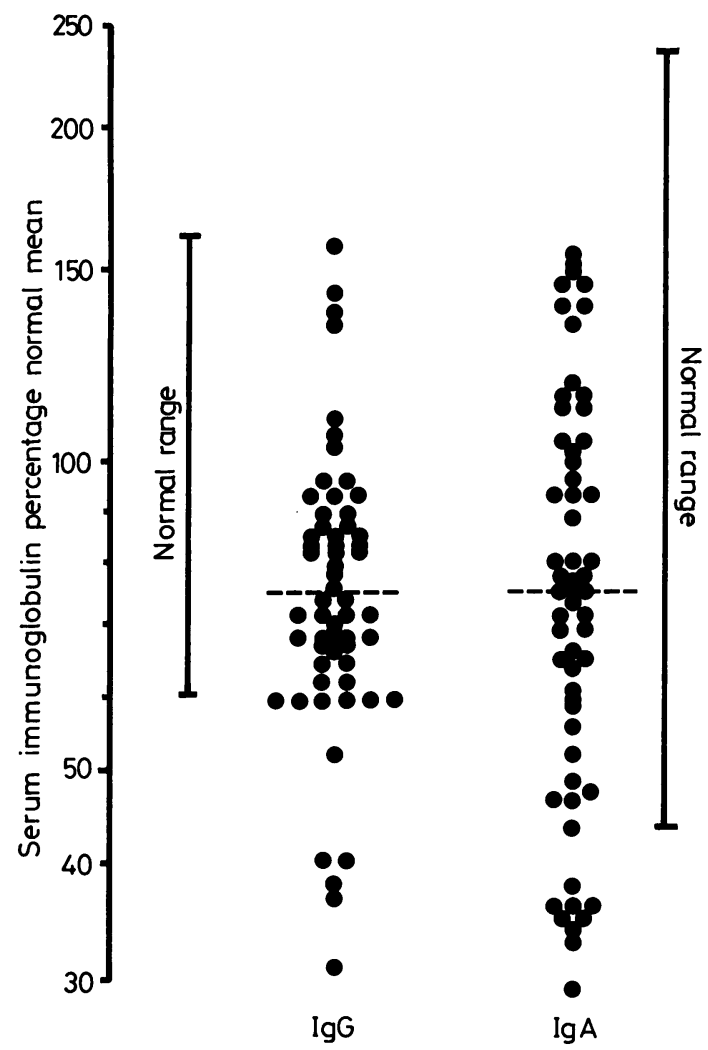

Fig. 2 Serum IgG and IgA levels in 60 children with steroid-responsive nephrotic syndrome. Immunoglobulin levels are converted to percentage mean values for age. Dotted line shows mean value.

normal range. Forty-two had a percentage mean value below $100 \%$. The mean value for the nephrotic children was $77 \%$ (Fig. 2).

\section{IgM}

Of 63 nephrotic children, 39 had a value within the normal range, and 25 had a value significantly above the normal range. Sixty-two had a percentage mean value above $100 \%$. The mean level for the nephrotic children was $183 \%$ (Fig. 3).

Control group. Of 37 children in the control group, 2 had an IgG level below the normal range. All had IgM levels within the normal range, 1 had an IgA value greater than the normal range. All other values were distributed randomly above and below the mean, within the normal range.

Linear regression for paired samples of the 3 immunoglobulins showed that the only significant relationship was between serum IgG and serum IgA

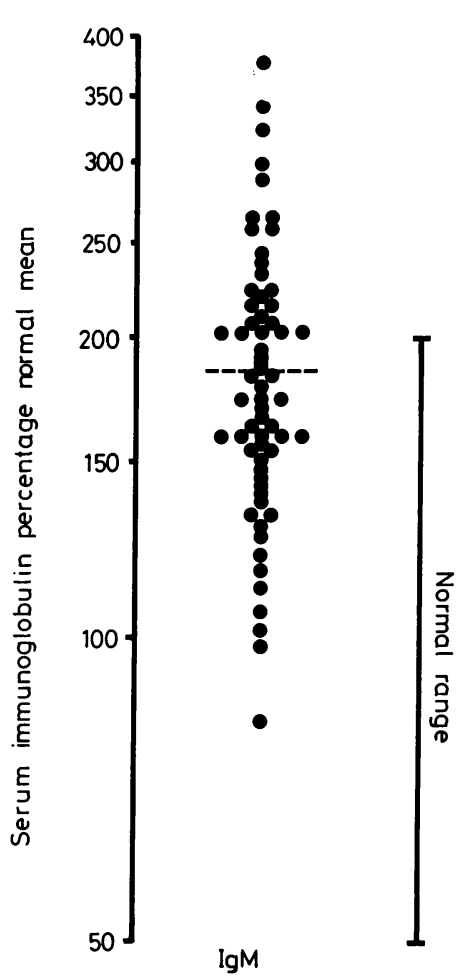

Fig. 3 Serum IgM levels in 63 children with steroidresponsive nephrotic syndrome. Immunoglobulin levels are converted to percentage mean values for age and gender. Dotted line shows mean value.

(60 paired samples showed a correlation coefficient of 0.91). Abnormal immunoglobulin levels occurred in both single and relapsing nephrotic syndrome. No contrasting trend was apparent.

Relationship to length of remission. Thirty-six of the children had been in remission for longer than one year at the time of immunoglobulin measurement. Their mean levels of serum immunoglobulin were similar to the group as a whole, with serum IgG being slightly higher. The mean levels were: IgG $85 \%$ (compared with $76 \%$ ), IgA $76 \%$ (compared with $77 \%$ ), IgM $182 \%$ (compared with $183 \%$ ).

Relationship to IgE levels. Of 24 children who had serum IgE levels $>500 \mathrm{IU} / \mathrm{ml}$, only $6(25 \%)$ had normal levels for IgG, IgA, and IgM. The abnormalities were: low IgG (in 3), raised IgM (in 11), low $\operatorname{IgA}$ (in 4).

Of 39 children who had a serum IgE $<500 \mathrm{IU} / \mathrm{ml}$, $18(46 \%)$ had normal levels of IgG, IgA, and IgM. However, analysis of all the paired samples did not 
show a significant relationship between serum IgE and either IgG, IgA, or IgM.

Immunofluorescent examination of renal tissue. Renal tissue which was satisfactory for immunofluorescent study was obtained from 25 children. Five children were in relapse at the time of the biopsy, a further 11 had had a recent relapse and had been in remission for less than 7 days. Of these 25 children, 3 had serum IgE levels $>1000 \mathrm{IU} / \mathrm{ml}$ and another 2 children had serum IgE levels in the high range of $500-1000 \mathrm{IU} / \mathrm{ml}$.

Significant deposits of IgE were not detected in the glomeruli or elsewhere in the kidney tissue. Some renal tissue contained minimal deposits of IgM or other immunofluorescent material which

Table 7 HLA frequencies in different categories of nephrotic children compared with the frequency in a control group

\begin{tabular}{|c|c|c|c|c|c|c|c|c|c|c|c|}
\hline \multirow[t]{2}{*}{ Antigen } & \multirow{2}{*}{$\begin{array}{l}\text { Controls } \\
(\%)\end{array}$} & \multicolumn{2}{|c|}{ Nephrotic syndrome* } & \multicolumn{2}{|c|}{ Relapsing nephrotic $\dagger$} & \multicolumn{2}{|c|}{ Single nephrotic $\ddagger$} & \multicolumn{2}{|c|}{ Non-atopic 8} & \multicolumn{2}{|c|}{ Atopic } \\
\hline & & No & $\%$ & No & $\%$ & No & $\%$ & No & $\%$ & No & $\%$ \\
\hline $\begin{array}{r}\text { A } 1 \\
\\
2 \\
3 \\
9 \\
9 \\
10 \\
11 \\
28\end{array}$ & $\begin{array}{r}37 \\
49 \\
25 \\
18 \\
7 \\
13 \\
7\end{array}$ & $\begin{array}{r}29 \\
32 \\
12 \\
6 \\
2 \\
10 \\
14\end{array}$ & $\begin{array}{r}40 \\
44 \\
17 \\
8 \\
3 \\
14 \\
19\end{array}$ & $\begin{array}{r}24 \\
30 \\
10 \\
6 \\
2 \\
9 \\
10\end{array}$ & $\begin{array}{r}39 \\
49 \\
16 \\
10 \\
3 \\
15 \\
16\end{array}$ & $\begin{array}{l}5 \\
4 \\
2 \\
0 \\
0 \\
1 \\
4\end{array}$ & $\begin{array}{r}45 \\
36 \\
18 \\
0 \\
0 \\
9 \\
36\end{array}$ & $\begin{array}{r}19 \\
24 \\
9 \\
5 \\
2 \\
4 \\
10\end{array}$ & $\begin{array}{r}40 \\
50 \\
19 \\
10 \\
4 \\
8 \\
21\end{array}$ & $\begin{array}{l}8 \\
8 \\
4 \\
1 \\
0 \\
6 \\
4\end{array}$ & $\begin{array}{r}38 \\
38 \\
19 \\
5 \\
0 \\
29 \\
19\end{array}$ \\
\hline $\begin{array}{r}\text { B } 5 \\
7 \\
8 \\
12 \\
13 \\
14 \\
\text { W15 } \\
17 \\
18 \\
\text { W35 } \\
\text { W40 } \\
\text { W22 } \\
27\end{array}$ & $\begin{array}{r}9 \\
29 \\
25 \\
31 \\
4 \\
8 \\
14 \\
9 \\
8 \\
13 \\
10 \\
3 \\
7\end{array}$ & $\begin{array}{r}6 \\
16 \\
25 \\
26 \\
5 \\
5 \\
13 \\
8 \\
4 \\
6 \\
4 \\
3 \\
6\end{array}$ & $\begin{array}{r}8 \\
22 \\
35 \\
26 \\
7 \\
7 \\
18 \\
11 \\
6 \\
8 \\
6 \\
4 \\
8\end{array}$ & $\begin{array}{r}5 \\
14 \\
22 \\
24 \\
4 \\
3 \\
10 \\
5 \\
4 \\
4 \\
3 \\
3 \\
6\end{array}$ & $\begin{array}{r}8 \\
23 \\
36 \\
39 \\
7 \\
5 \\
16 \\
8 \\
7 \\
7 \\
5 \\
5 \\
10\end{array}$ & $\begin{array}{l}1 \\
2 \\
3 \\
2 \\
1 \\
2 \\
3 \\
3 \\
0 \\
2 \\
1 \\
0 \\
0\end{array}$ & $\begin{array}{r}9 \\
18 \\
27 \\
18 \\
9 \\
18 \\
27 \\
27 \\
0 \\
18 \\
9 \\
0 \\
0\end{array}$ & $\begin{array}{r}5 \\
10 \\
18 \\
21 \\
4 \\
2 \\
8 \\
6 \\
1 \\
4 \\
2 \\
1 \\
4\end{array}$ & $\begin{array}{r}10 \\
21 \\
37 \\
44 \\
8 \\
4 \\
17 \\
12 \\
2 \\
8 \\
4 \\
2 \\
8\end{array}$ & $\begin{array}{l}1 \\
6 \\
6 \\
4 \\
1 \\
2 \\
5 \\
2 \\
3 \\
2 \\
2 \\
2 \\
2\end{array}$ & $\begin{array}{r}5 \\
29 \\
29 \\
19 \\
5 \\
10 \\
24 \\
10 \\
14 \\
10 \\
10 \\
10 \\
10\end{array}$ \\
\hline
\end{tabular}

* 72 children with nephrotic syndrome. $\$ 61$ children with nephrotic syndrome and frequent relapses. $¥ 11$ children with nephrotic syndrome with one single episode. $\$ 48$ children with nephrotic syndrome who did not give a history of atopic disease. I 24 children with nephrotic syndrome who did give a history of atopic disease.

Table 8 HLA frequencies in nephrotic children compared with the frequency in a control group

\begin{tabular}{|c|c|c|c|c|c|c|c|c|c|c|c|}
\hline \multirow[t]{2}{*}{ Antigen } & \multirow[t]{2}{*}{$\begin{array}{l}\text { Controls } \\
(\%)\end{array}$} & \multicolumn{2}{|c|}{ Cyclophosphamide* } & \multicolumn{2}{|c|}{$\begin{array}{l}\text { Cyclophosphamide } \\
\text { and remission } \dagger\end{array}$} & \multicolumn{2}{|c|}{$\begin{array}{l}\text { Cyclosphosphamide } \\
\text { and relapse } \ddagger\end{array}$} & \multicolumn{4}{|c|}{ Skin tests§ } \\
\hline & & $N o$ & $\%$ & No & $\%$ & No & $\%$ & Positive & $\%$ & Negative & $\%$ \\
\hline $\begin{array}{rr}\text { A } & 1 \\
& 2 \\
& 3 \\
9 & 9 \\
10 \\
11 \\
\\
28\end{array}$ & $\begin{array}{r}37 \\
49 \\
25 \\
18 \\
7 \\
13 \\
7\end{array}$ & $\begin{array}{r}13 \\
15 \\
7 \\
2 \\
1 \\
4 \\
6\end{array}$ & $\begin{array}{r}38 \\
44 \\
21 \\
6 \\
3 \\
12 \\
18\end{array}$ & $\begin{array}{r}9 \\
13 \\
5 \\
2 \\
1 \\
2 \\
6\end{array}$ & $\begin{array}{r}32 \\
46 \\
18 \\
7 \\
4 \\
7 \\
21\end{array}$ & $\begin{array}{l}4 \\
2 \\
2 \\
0 \\
0 \\
2 \\
0\end{array}$ & $\begin{array}{r}67 \\
33 \\
33 \\
0 \\
0 \\
33 \\
0\end{array}$ & $\begin{array}{r}12 \\
14 \\
7 \\
4 \\
1 \\
8 \\
7\end{array}$ & $\begin{array}{r}33 \\
39 \\
19 \\
11 \\
3 \\
22 \\
19\end{array}$ & $\begin{array}{r}14 \\
18 \\
5 \\
2 \\
1 \\
2 \\
7\end{array}$ & $\begin{array}{r}44 \\
57 \\
16 \\
6 \\
3 \\
6 \\
22\end{array}$ \\
\hline $\begin{array}{r}5 \\
7 \\
8 \\
12 \\
13 \\
14 \\
\text { W15 } \\
17 \\
18 \\
\text { W35 } \\
\text { W40 } \\
\text { W22 } \\
27\end{array}$ & $\begin{array}{r}9 \\
29 \\
25 \\
31 \\
4 \\
8 \\
14 \\
9 \\
8 \\
13 \\
10 \\
3 \\
7\end{array}$ & $\begin{array}{r}4 \\
10 \\
11 \\
17 \\
0 \\
0 \\
5 \\
4 \\
1 \\
1 \\
3 \\
1 \\
1\end{array}$ & $\begin{array}{r}12 \\
29 \\
32 \\
50 \\
0 \\
0 \\
15 \\
12 \\
3 \\
3 \\
9 \\
3 \\
3\end{array}$ & $\begin{array}{r}3 \\
8 \\
8 \\
13 \\
0 \\
0 \\
5 \\
3 \\
1 \\
1 \\
3 \\
1 \\
0\end{array}$ & $\begin{array}{r}11 \\
29 \\
29 \\
46 \\
0 \\
0 \\
18 \\
11 \\
4 \\
4 \\
11 \\
4 \\
0\end{array}$ & $\begin{array}{l}1 \\
2 \\
3 \\
4 \\
0 \\
0 \\
0 \\
1 \\
0 \\
0 \\
0 \\
0 \\
1\end{array}$ & $\begin{array}{r}17 \\
33 \\
50 \\
67 \\
0 \\
0 \\
0 \\
17 \\
0 \\
0 \\
0 \\
0 \\
17\end{array}$ & $\begin{array}{r}2 \\
8 \\
11 \\
12 \\
3 \\
2 \\
6 \\
2 \\
4 \\
4 \\
4 \\
2 \\
3\end{array}$ & $\begin{array}{r}6 \\
22 \\
31 \\
33 \\
8 \\
6 \\
17 \\
6 \\
11 \\
11 \\
11 \\
6 \\
8\end{array}$ & $\begin{array}{r}4 \\
7 \\
12 \\
13 \\
2 \\
2 \\
7 \\
6 \\
0 \\
2 \\
0 \\
1 \\
3\end{array}$ & $\begin{array}{r}12 \\
22 \\
37 \\
41 \\
6 \\
6 \\
22 \\
19 \\
0 \\
6 \\
0 \\
3 \\
9\end{array}$ \\
\hline
\end{tabular}

* 34 children with nephrotic syndrome who had received cyclophosphamide. +28 children who had received cyclophosphamide and with its help had achieved remission for at least a year. ¥Six children who had received cyclophosphamide but had relapsed within a year. $\$ N e p h r o t i c$ children who had positive $(n=36)$ or negative $(n=31)$ skin tests. 
were just visible as fine granular deposits affecting short segments of the basement membrane of an isolated glomerulus. However, despite intensive search there was no suggestion of a positive reaction for IgE.

HLA antigens. The HLA antigen frequency in 72 children with steroid-responsive nephrotic syndrome is shown in Tables 7 and 8. The frequencies in the nephrotic children were compared with those in the control group to detect if any significant difference existed between various subgroups of nephrotic children. Some frequencies at first glance suggested there was a significant difference from the control, but subsequent analysis showed that most differences were not significant. The main differences were an increase of HLA-A28 in nephrotics $(P=0.02)$, single nephrotics $(\mathrm{P}<0.02)$, and in non-atopic nephrotics $(P=0.02)$ compared with the controls.

Haplotype HLA-A1/HLA-B8

This haplotype was present in 17 of the children. It was present in 12 of 48 children classified as nonatopic and in 5 of 21 atopic children. Thus it was present in both groups in a similar proportion of cases.

\section{Discussion}

Serum total IgE levels increase with age. In the age group chosen for this study non-atopic children should have levels below $100 \mathrm{IU} / \mathrm{ml}$. A level greater than $500 \mathrm{IU} / \mathrm{ml}$ is a useful detector of atopic disease. ${ }^{17}$

Serum total IgE was significantly raised in the nephrotic children compared with controls and also compared with other data. ${ }^{18}$ The higher levels were associated in some children with a history of atopy, but other children had no such history. Perhaps these children will develop an atopic disorder, or perhaps nephrotic syndrome itself is such a manifestation. Relapsing nephrotic syndrome was more often associated with high IgE levels than single nephrotic syndrome.

The group of children with very high IgE levels $(>1000 \mathrm{IU} / \mathrm{ml}$ ) are surprising, particularly as 3 of them did not give a history of an atopic disorder.

The total IgE level fell after treatment with cyclophosphamide; in 3 children it fell from levels in the range $4400-10000 \mathrm{IU} / \mathrm{ml}$ to levels in the range 45-240 IU $/ \mathrm{ml}$. These falls were confirmed by repeating the measurement on the same plate to reduce technical error (the longer storage time of the first serum sample, if significant, would be expected to decrease the difference). Sampling was scattered throughout the year so that seasonal factors are unlikely to have contributed to the change in IgE levels, particularly as repeat measurements on other children showed seasonal factors to have little effect. All children were in sustained remission (from nephrotic syndrome) at the time of blood taking, so that the significant changes in IgE level were likely to be caused by the treatment with cyclophosphamide. Corticosteroid therapy, in the dosage used, was not associated with large IgE changes.

The conclusion that an 8-week course of treatment with cyclophosphamide reduces the serum total IgE in nephrotic children could explain why children who had had cyclophosphamide had lower IgE levels in the series reported by Groshong and colleagues. ${ }^{19}$ It is unlikely that cyclophosphamide influences the chance of exposure to specific antigens. It is more likely that it reduces total $\mathrm{IgE}$ as a result of its cytotoxic activity on IgE production. A fall of IgE level took place in children for whom cyclophosphamide was fairly unhelpful as well as in those whom it helped to achieve a remission of more than one year.

The RAST identification of specific IgE has shown itself to be a useful in vitro test for atopic allergy. Positive tests in healthy people are rare, probably less than $1 \%{ }^{20} 35 \%$ of the nephrotic children had at least one positive test. If it had been feasible to repeat the test on several occasions the proportion would have been higher since specific IgE levels rise on exposure to the relevant antigen. Positive tests to house-dust mite and cat fur were the most common findings, and fit in with the increased incidence of atopic disorders that we found in the nephrotic children.

The nephrotic children tended to have low levels of IgG and IgA and raised levels of IgM compared with both the control group and the standards available for normal immunoglobulin levels at different ages. In a few cases the serum levels were outside the normal range. Abnormal values of IgA, IgG, or IgM were more common in children with raised levels of serum total IgE.

Children in relapse leaking large amounts of protein in their urine have reduced levels of serum IgG and IgA regardless of the cause of the nephrotic syndrome. This may be a result of redistribution into extravascular fluid associated with hypoalbuminaemia, or a result of urinary loss. The children were all in remission at the time of the investigations; most had been in remission for several months, although a few had been in remission for as short a time as 4 weeks. It is likely that one or two of the very low levels for IgA and IgG can be explained by insufficient time having been allowed between remission and the blood test. However, that cannot explain all the low levels nor does it explain the general trend (Figs 2 and 3). The levels for those 
children who had been in remission for at least a year were similar to those for the whole group. Our findings agree with those of the St Louis group ${ }^{21}$ and also with a study in Mexico (G Gordillo, 1978, personal communication). It may be significant that a relative deficiency of IgA or IgG tends to accompany atopic disorders. ${ }^{22}$

At least five studies confirm the finding of raised serum IgM in nephrotic children who are in remission. Only in one study were normal levels found. ${ }^{23}$ Both the St Louis and the Mexico studies found that IgM level was raised in children with idiopathic minimal change nephrotic syndrome but was not raised in children with nephrotic syndrome secondary to other forms of glomerulonephritis (for example membranoproliferative glomerulonephritis). Thus the association of raised serum IgM seems to be with minimal change disease rather than with nephrotic syndrome itself.

Raised levels of serum IgM are found in several diseases including chronic viral infections. Children with steroid-responsive nephrotic syndrome are strikingly healthy between relapses and it is unlikely that a persistent virus is awaiting discovery. IgM is produced early by the body in response to an appropriate stimulus: $\operatorname{IgG}$ and $\operatorname{IgA}$ follow. A difficulty in changing from IgM production to IgG and $\operatorname{IgA}$ production could explain the immunoglobulin findings. That would point towards an abnormality of T-cell function. The children had a raised IgM level as late as 7 years after the last relapse. If it is considered that the raised IgM level indicates a propensity to developing nephrotic syndrome it seems that despite that propensity, changes occur in either the environment or the person to lessen that propensity as the child reaches puberty.

IgE was not detected in renal tissue from 25 children. Several of these children had atopic disorders and several had high serum IgE levels. Gerber and Paronetto ${ }^{24}{ }^{25}$ reported the presence of IgE in the glomeruli of 7 children who had minimal change nephrotic syndrome. Subsequent reports from elsewhere have been negative; in particular Robertson et al. ${ }^{26}$ found no IgE in 18 patients. One aspect that has sometimes been overlooked is that Gerber and Paronetto ${ }^{24} 25$ reported IgE to be present at the time of relapse and absent during remission. Most renal biopsies are done during remission when it is safer and they are easier to perform. Many reports fail to state the timing of their biopsies in relation to relapse, but as our study included many children in relapse or within 7 days of the start of remission it is unlikely that IgE was missed because of the timing of the biopsy.

The most convincing cases of nephrotic syndrome caused by grass pollen allergy are those reported by Reeves et al. ${ }^{27}$ Their studies were extensive and included several immunofluorescent studies of biopsied material from a pollen-sensitive patient in relapse. No IgE was found in renal tissue, although serum levels had shown a pronounced seasonal increase in both total IgE and specific IgE. The conclusion must be that IgE is not detectable in renal tissue from children with nephrotic syndrome. It could be suggested that it is present, but in very small quantities. If its biological activity were many times greater than IgG, a tiny amount could correspond to a strongly positive reaction for IgG. The

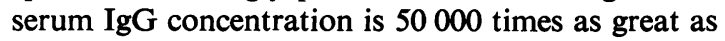
IgE. If the same applied to renal deposits IgE would be likely to be considered negative by current techniques. Nevertheless, even if IgE were present in minute quantities in the kidney it is difficult to postulate a role for it there. Mast cells are scanty in the kidney and if a role has to be found for IgE in the genesis of nephrotic syndrome it is more likely to be an indirect activity (by means of chemical mediators) from a distant site.

No significant association was found between the frequency of certain HLA antigens and nephrotic syndrome or the various subgroups studied. Many comparisons were made in the hope of finding an association which could be useful in clinical practice. No useful association with HLA antigens was found. From consideration of the allergic aspect this might have been expected since HLA linkage with atopy is weak. However, surveys of nephrotic children from the Institute of Child Health, London $^{28}{ }^{29}$ found a significant excess of HLA-B12, and noted that positive skin tests to Timothy grass pollen and raised serum IgE levels were also more common in nephrotic children carrying the HLAB12 antigen. They also found an excess of the haplotype HLA-A1/HLA-B8 particularly in nonatopic nephrotic children. Our findings did not confirm their report.

Both this study and the associated study ${ }^{1}$ show that clinical and immunological features of atopy are more common in children with steroid-responsive nephrotic syndrome. This could be a causal or a non-causal association. The fact that pollen hypersensitivity nephrotic syndrome exists, and that it responds to avoidance and desensitisation measures means that it is worth pursuing the search for identifiable allergenic causes. Careful history taking and attention to the environmental circumstances may disclose provocative agents other than pollen as a cause of nephrotic syndrome.

We thank the paediatricians who referred the children, the staff in Leeds who helped in their care 
and investigation, the Medical Illustration Department, St James's University Hospital, and our assistant Mrs Wendy Pearson.

The Children's Kidney Fund, University of Leeds, provided financial support.

\section{References}

1 Meadow S R, Sarsfield J K. Steroid-responsive nephrotic syndrome and allergy: clinical studies. Arch Dis Child 1981; 56: 509-16.

2 Mancini G, Carbonara A O, Heremans J F. Immunochemical quantitation of antigens by single radial immunodiffusion. Immunochemistry 1965; 2: 235-54.

3 Hobbs J R. Simplified radial immunodiffusion. Association of Clinical Pathologists Broadsheet 1970: 68.

- Allansmith M, McClellan B H, Butterworth M, Maloney J R. The development of immunoglobulin levels in man. $J$ Pediatr 1968; 72: 276-90.

5 Buckley R H, Dees S C, O'Fallon W M. Serum immunoglobulins. I. levels in normal children and in uncomplicated childhood allergy. Pediatrics 1968; 41: 600-11.

- Johansson S G O, Berg T. Immunoglobulin levels in healthy children. Acta Paediatr Scand 1967; 56: 572-9.

7 Stege N, Gugler E. Die quantitative Bestimmung der Immunoglobulinreifung mit Hilfe der einfachen radialen Immunodiffusionsmethode. Helv Paediatr Acta 1968; 23: 242-50.

8 Stiehm E R, Fudenberg H H. Serum levels of immune globulins in health and disease: a survey. Pediatrics 1966; 37: 715-27.

- Stoop J W, Zegers B J M, Sander P C, Ballieux R E. Serum immunoglobulin levels in healthy children and adults. Clin Exp Immunol 1969; 4: 101-12.

10 Ceska $M$, Lundkvist U. A new and simple radio-immunoassay method for the determination of IgE. Immunochemistry 1972; 9: 1021-30.

11 Rowe D S, Tackett L, Bennich H, Ishizaka K, Johansson S G O, Anderson S G. A research standard for human serum immunoglobulin E. Bull WHO 1970; 43: 609-11.

12 Wide L, Bennich $\mathrm{H}$, Johansson $\mathrm{S} G \mathrm{O}$. Diagnosis of allergy by an in vitro test for allergen antibodies. Lancet 1967; ii: $1105-7$.

13 White $R \mathbf{H} R$. Observations on percutaneous renal biopsy in children. Arch Dis Child 1963; 38: 260-6.

14 Terasaki P I, McClelland J D. Microdroplet assay of human serum cytotoxins. Nature 1964 ; 204: 998-1000.

15 Böyum A. Isolation of mononuclear cells and granulocytes from human blood. Isolation of mononuclear cells by one centrifugation, and of granulocytes by combining centrifugation and sedimentation at 1g. Scand J Clin Lab Invest 1968; 21 : Supplement 97, 77-89.

16 Grumet F C, Coukell A, Bodmer J G, Bodmer W F, McDevitt H O. Histocompatibility (HL-A) antigens associated with systemic lupus erythematosus. $N$ Engl $J$ Med 1971; 285: 193-6.

17 Kjellman N I M. Predictive value of high IgE levels in children. Acta Paediatr Scand 1976; 65: 465-71.

18 Kjellman N I M, Johansson S G O, Roth A. Serum IgE levels in healthy children quantified by a sandwich technique (PRIST). Clin Allergy 1976; 6: 51-9.

19 Groshong T, Mendelson L, Mendoza S, Bazaral M, Hamburger R, Tune B. Serum IgE in patients with minimal-change nephrotic syndrome. J Pediatr 1973; 83: 767-71.

20 Berg T L O, Johansson S G O, Allergy diagnosis with the radioallergosorbent test. J Allergy Clin Immunol 1976; 54 : 209-21.

21 Giangiacomo J, Cleary T G, Cole B R, Hoffsten P, Robson A M. Serum immunoglobulins in the nephrotic syndrome. N Engl J Med 1975; 293: 8-12.

22 Kaufman H S, Hobbs J R. Immunoglobulin deficiencies in an atopic population. Lancet 1970; ii: 1061-3.

23 Sobel A T, Intrator L, Lagrue G. Letter: Serum immunoglobulins in idiopathic minimal-change nephrotic syndrome. N Engl J Med 1976; 294: 50.

24 Gerber M A, Paronetto F. IgE in glomeruli of patients with nephrotic syndrome. Lancet 1971; i: 1097-9.

25 Gerber M A, Paronetto F. New patterns of immunoglobulin deposition in the lesions of malignant nephrosclerosis with special reference to IgE. Am J Pathol 1971; 65: $535-42$.

${ }^{26}$ Robertson M R, Potter E V, Roberts M L, Patterson R. Immunoglobulin E in renal disease. Nephron 1976; 16: 256-71.

27 Reeves W G, Cameron J S, Johansson S G O, Ogg C S, Peters D K, Weller R O. Seasonal nephrotic syndrome. Clin Allergy 1975; 5: 121-37.

28 Thomson P D, Stokes C R, Barratt T M, Turner M W, Soothill J F. HLA antigens and atopic features in steroidresponsive nephrotic syndrome of childhood. Lancet 1976; ii: $765-8$.

29 Trompeter R S, Barratt T M, Kay R, Turner M W, Soothill J F. HLA atopy and cyclophosphamide in steroid-responsive childhood nephrotic syndrome. Kidney Int 1980; 17: 113-7.

Correspondence to Professor S R Meadow, Department of Paediatrics and Child Health, St James's University Hospital, Beckett Street, Leeds LS9 7TF.

Received 25 May 1980 